\title{
IGNEOUS PROTOLITHS OF THE BIHARIA LITHOTECTONIC ASSEMBLAGE: TIMING OF INTRUSION, GEOCHEMICAL CONSIDERATIONS, TECTONIC SETTING
}

\author{
PANĂ DINU ${ }^{1}$, BALINTONI IOAN ${ }^{2}$
}

\begin{abstract}
The oldest $\mathrm{U} / \mathrm{Pb}$ isotopic age data for the Apuseni Mountains were determined from the Biharia meta-igneous assemblage. Two granitoid bodies yielded 489,6 \pm 6,9 Ma and $502 \pm$ 4,2 Ma ages. The geochemical data suggest an island arc tectonic setting for the Biharia meta-igneous protholits.
\end{abstract}

\section{INTRODUCTION}

The Apuseni Mountains represent the largest basement exposure between the Carpathians and Dinarides branches of the Alpine orogen. Recent geodynamic models agree to a certain degree upon the Cenozoic extent, nature of boundaries and geodynamic evolution of the Apuseni crustal fragment (e.g., Kovács et al., 1989; Marton and Mauritsch, 1990; Csontos et al., 1992; Haas et al., 1995). However, the pre-Alpine to Early Alpine evolution of the crust is largely speculative and controversial due to the lack of analytical data. In some reconstructions (e.g., Sandulescu, 1988) the Apuseni Mountains belong to a large crustal fragment that includes the Austroalpine units of the Alps and hence would have an African origin. In other reconstructions (e.g., Balla, 1982), the Apuseni fragment is interpreted as a slice of European crust.

The European Alpine belt is superposed on the wider Variscan belt. The Variscan orogen is currently interpreted as a collage of various tectonostratigraphic units accreted along the northern margin of Gondwana during Devonian to Early Carboniferous transpressional collision (von Raumer, 1998). Extensive petrological and geochronological studies in the Alps and in the extra-Alpine Variscides have resulted in a relatively well constrained Late Proterozoic - Paleozoic evolutionary model. Attempts to integrate

\footnotetext{
${ }^{1}$ Alberta Geological Survey, 4th Floor, Twin Atria Building, 4999-98 Avenue, Edmonton, Alberta, Canada T6B $2 X 3$

${ }^{2}$ Department of Mineralogy, "Babeş-Bolyai" University, 3400 Cluj-Napoca, Cluj, Romania.
} 
basement units from southeastern Europe into the model are based almost exclusively on lithostratigraphic correlations (e.g., Kräutner, 1988; von Raumer and Neubauer, 1993). Precambrian and Paleozoic tectonothermal events have been inferred in the basement units of the Apuseni Mountains (e.g., Giuşcă et al., 1968; Kräutner, 1980; Dimitrescu, 1985). A widespread low-grade Alpine overprint (Pană and Erdmer, 1994) affected the basement units of the Apuseni Mountains. Alpine vs. Variscan tectonothermal evolution has been recently constrained by ${ }^{40} \mathrm{Ar} /{ }^{39} \mathrm{Ar}$ data on metamorphic rocks (Dallmeyer et al., 1999).

We present geochemical data from igneous protoliths of the Biharia igneous complex of the Apuseni Mountains and U-Pb data from two of its major granitoid pods, in an attempt to reveal the pre-Alpine geological framework of the region. Our data indicate that the Alpine HBSZ overprinted two igneous complexes of distinct ages and geochemistry. We propose a preliminary interpretation of their Paleozoic tectonic setting. However, further extensive petrological studies are needed to substantiate the appurtenance of a dated magmatic event to a certain pre-Alpine geotectonic setting in order to attempt the reconstruction of the Variscan orogen anatomy.

\section{GEOLOGICAL SETTING, PREVIOUS ISOTOPE DATA}

Amphibolite-, epidote-amphibolite-, and greenschist facies lithotectonic assemblages characterize the central and northern Apuseni Mountains (e.g., Giuşcă et al., 1968, Dimitrescu 1985). These metamorphic rocks were thought to record respectively Middle Proterozoic, Late Proterozoic/Cambrian or Caledonian, and Variscan tectonomagmatic cycles (e.g., Dimitrescu, 1985, Kräutner, 1988), but little age control was available. The lithotectonic assemblages formed in each of the tectonomagmatic cycles were inferred to be separated by stratigraphic or metamorphic unconformities. However, the location and nature of assemblage boundaries remain controversial (Balintoni, 1985; 1994; Dimitrescu, 1988). Existing K-Ar isotopic data (Soroiu et al., 1969; Pavelescu et al., 1975) of little or no geological significance in polymetamorphic rocks, are scattered over a wide range and inconsistent with the above evolution model. Emplacement ages of intrusive rocks were assigned based on the assumed age of tectonism in the surrounding metamorphic assemblages.

The recent recognition of a large component of non-coaxial strain and of the occurrence of retrograde metamorphic minerals in the lowestgrade assemblages (Pană and Erdmer, 1994) and ${ }^{40} \mathrm{Ar} /{ }^{39} \mathrm{Ar}$ isotopic dating (Dallmeyer et al., 1999) have led to the interpretation that the assemblages outline a zone of regional Alpine strain concentration, the Highiş-Biharia shear zone (HBSZ). The zone can be traced for $150 \mathrm{~km}$ from the Pannonian Basin across the Apuseni Mountains to the Transylvanian Basin (Fig. 1). Contrasting metamorphic rocks border the shear zone: to the north, the Someş gneiss- 
granite assemblage and the Codru amphibolite-granitoid rock assemblage, and to the south, the Baia de Arieş carbonate-lense gneissic assemblage.

The Alpine HBSZ includes several low-grade lithotectonic assemblages derived from volcano-(?)sedimentary sequences and associated plutons. These are defined by distinct lithologic and mineral relics, but have no stratigraphic connotation. In the axial zone of the belt the rocks are phyllonite and metre to kilometre size igneous pods. Igneous textures are progressively obliterated towards the peripheries of the pods until completely losing their identity within the phyllonitic matrix. The igneous rocks show a range of chemical compositions and grain-sizes indicative for an upper crustal igneous complex.

In the westernmost segment of the HBSZ, the Highis Mountains expose an igneous complex, tens of square kilometres wide, wrapped in a mesh of phyllonite with undigested pods of igneous rocks.

The Highiş igneous complex consists of an alkaline suite originated in the metasomatized continental mantle (Tatu,1998). The tectonic setting has been extensional during the magma generation and the granites evolved from a basic melt through fractional crystallization.

The igneous rocks were previously interpreted to intrude a prograde greenschist facies assemblage and were consequently assigned to the Variscan event (e.g. Giuşcă et al. 1968). However, K/Ar age data ranging from 75 to $123 \mathrm{Ma}$ (Soroiu, et al. 1969; Pavelescu et al., 1975) and ${ }^{40} \mathrm{Ar} /{ }^{39} \mathrm{Ar}$ plateau ages of 100-114 Ma on the low-grade rocks (Dallmeyer et al. 1999) indicate Early to Middle Cretaceous tectonism. A 350 Ma whole rock K/Ar age is the only isotope data reported so far on a granite sample from the Highiş Mountains (Giuşcă et al. 1968). Recent U-Pb zircon data indicate a late Early Permian short-lived igneous event. Timing of emplacement for the Highiş igneous complex is bracketed by the early Cladova alkaline diorite emplaced at c. $267 \pm 4 \mathrm{Ma}$ and the late porphyritic microgranite emplaced at c. $264 \pm 2 \mathrm{Ma}$.

Along the HBSZ to the east, in the Biharia and Gilău mountains weakly to highly sheared granitoid units are interlayered with subordinate phyllonite. Sheared and hydrated diorite bodies were previously interpreted as epidoteamphibolite facies clastic sediments and consequently assigned to the Caledonian event (e.g. Dimitrescu, 1985;1988). Balintoni (1986) interpreted the mafic rocks from Highiş and Biharia mountains to represent Caledonian ophiolitic crust and the granitic rocks to represent the Variscan magmatism. This model also assumes two metamorphic events contemporaneous with the intrusions, although the only available data were $\mathrm{K}-\mathrm{Ar}$ ages ranging from 143 to $76 \mathrm{Ma}$ (Pavelescu et al., 1975). An ${ }^{40} \mathrm{Ar} /{ }^{39} \mathrm{Ar}$ plateau age of $108 \mathrm{Ma}$ was 
PANĂ DINU, BALINTONI IOAN

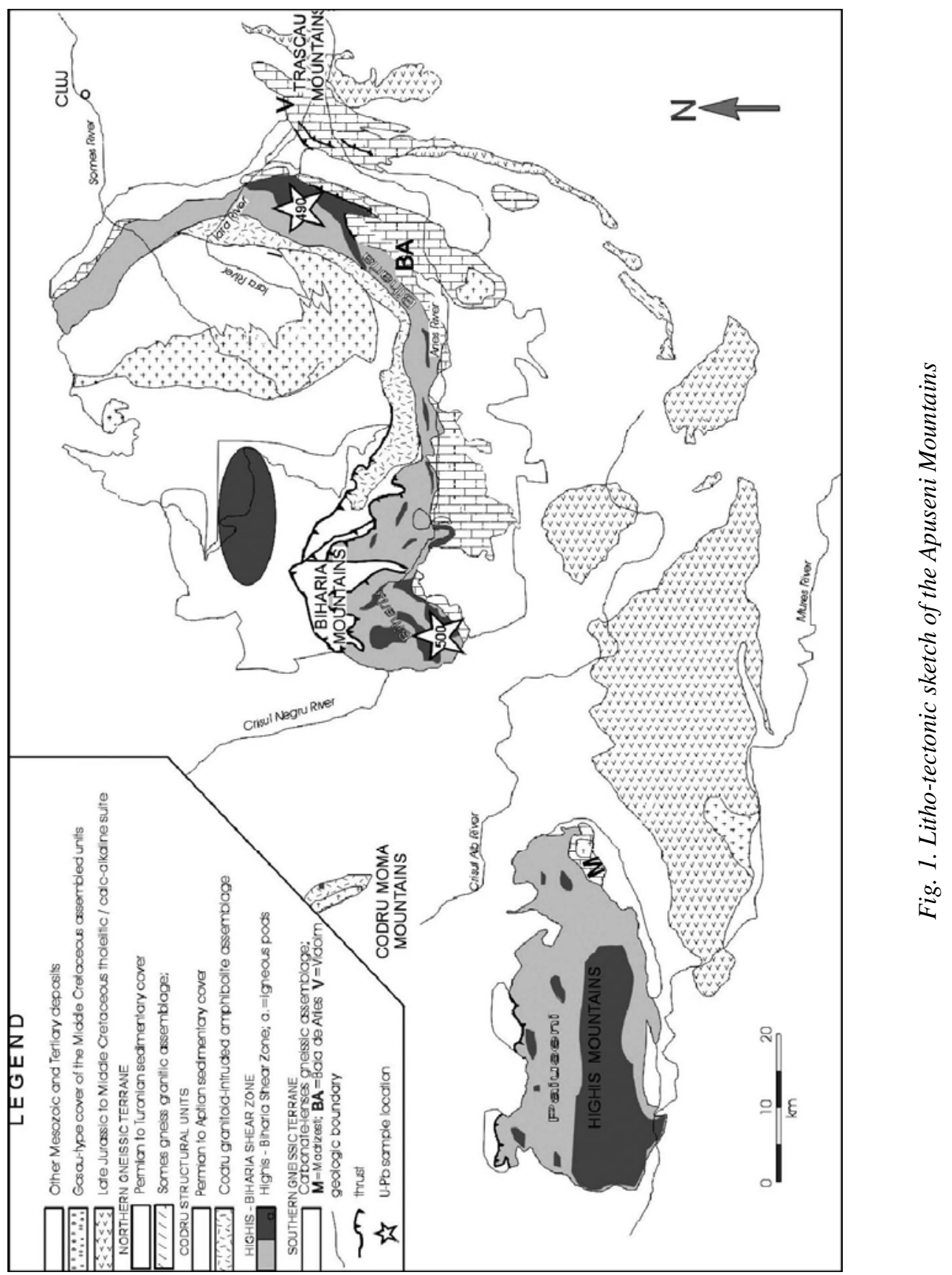


recently reported (Dallmeyer et al. 1999). In the central and eastern HBSZ, $\mathrm{K}-\mathrm{Ar}$ dates range from 143 to $76 \mathrm{Ma}$ (Pavelescu et al., 1975). In the Biharia Mountains, an ${ }^{40} \mathrm{Ar} /{ }^{39} \mathrm{Ar}$ plateau date of $108 \mathrm{Ma}$ and several Jurassic and Cretaceous total gas dates have been obtained from phyllonite (Dallmeyer et al., 1999). Preliminary U-Pb data on the Leucii granite from the Biharia Mountains suggested an emplacement age of c. 516 Ma (Pană, 1998). ${ }^{207} \mathrm{~Pb} /{ }^{206} \mathrm{~Pb}$ dates for a non-abraded and an abraded fractions are c. 501 and c. 502 , respectively (Table 1 ). The regression line passing through the 2 analysis intersected the concordia line at $516 \pm 8 \mathrm{Ma}$ and c. $4 \mathrm{Ma}$. Although inheritance cannot be precluded, the upper intersect was tentatively interpreted as the best estimate of the emplacement age.

Whilst no medium-grade relics exist within the axial zone of the belt, toward the peripheries, retrogressed medium grade protoliths can be traced into the adjacent mediu-grade assemblages. To the north, HBSZ is bounded by the Codru assemblage which consists of a discontinuous belt of orthoamphibolite and their gabbroic protolith, invaded by multiple phases of diorite to granite intrusions. The cross-cutting relationships within individual exposures are difficult to correlate due to the limited size and variable chemistry of the granitoid bodies and widespread low-grade shearing. Twomica gneisses are interlayered mainly in the western part and appear to be derived from two mica granodiorite. K/Ar data on rocks assigned to the Codru assemblage range between 243-596 Ma (Giuşcă et al., 1968; Soroiu et al., 1969; Pavelescu, et al., 1975). Recent ${ }^{40} \mathrm{Ar} /{ }^{39} \mathrm{Ar}$ data on an hornblende concentrate from the orthoamphibolite and muscovite from gneiss samples yielded ages of 366 to $405 \mathrm{Ma}$ and 335 to $340 \mathrm{Ma}$, respectively (Dallmeyer et al., 1999).

The lithology gradually changes northward into the Someş assemblage, dominated by monotonous micaceous gneisses, with interlayers of quartzofeldspathic gneisses and scarce amphibolite. The presence of garnet and staurolite zone followed by local sillimanite growth have been interpreted as evidence for a poly-metamorphic evolution (Hârtopanu and Hârtopanu, 1986). The Someş assemblage is intruded by the Muntele Mare granite. The contact is overprinted by a kilometre wide biotite to chlorite zone normal detachment. K/Ar data on the Someş assemblage yielded a wide range of values 77- $381 \mathrm{Ma}$ (Soroiu et al., 1969; Pavelescu, et al., 1975). ${ }^{40} \mathrm{Ar} /{ }^{39} \mathrm{Ar}$ data on hornblende and muscovite concentrates yielded ages of 316$306 \mathrm{Ma}$ and 303-314 Ma, respectively and were interpreted to date rapid cooling following the Variscan metamorphic event (Dallmeyer et al., 1999).

To the south, the low-grade assemblages of HBSZ are bounded by a gneissic assemblage dominated by kilometre-size lenses of variable dolomitic marble. The contact is gradational and often obscured by sheared granites of uncertain appurtenance. The gneiss-carbonate assemblage crops out in several isolated 'islands' along the southern margin of the Apuseni crustal fragment (Fig. 1). From west to east these are the Madrigesti, Baia de Arieş and Vidolm exposures of gneiss-carbonate assemblages. Unfortunately, detailed lithologic correlation is not possible, so different local names are still in use. However, a striking lithologic difference compared to the northern Someş assemblage is 
the presence of carbonate rocks with similar C-O isotopic signature (Pană et al., 1996) in all these relatively limited gneissic exposures south of HBSZ. The gneisses are intruded by concordant granite bodies up to several hundreds metres in size at Mădrigesti and by the Vința stock at Baia de Arieş. A polyphase tectonometamorphic evolution is indicated by metamorphic textures and ${ }^{40} \mathrm{Ar} /{ }^{39} \mathrm{Ar}$ data. Different ${ }^{40} \mathrm{Ar} /{ }^{39} \mathrm{Ar}$ cooling ages in different 'islands' suggest heterochroneous Alpine tectonism along the now, southern margin of the Apuseni crustal fragment from Middle Jurassic (156 Ma, Vidolm) to EarlyMiddle Cretaceous (111-119 Ma, Baia de Arieş) (Dallmeyer et al., 1999).

\section{GENERAL GEOCHEMICAL CHARACTERISTICS OF THE IGNEOUS PODS IN THE BIHARIA LITHOTECTONIC ASSEMBLAGE}

A major and trace element geochemical study of the igneous pods was carried out in an attempt to understand the tectonic significance of the Biharia igneous belt separating the two gneissic assemblages and to reconstruct the pre-Alpine tectonic framework of the region. A number of 46 samples from the igneous pods have been analysed for major and trace elements at the Chemical Analysis Laboratory of the Geological Survey of Romania. A summary of the geochemical analyses is presented in Tables I and II.

General geochemical characteristics of the igneous rocks from Biharia-Gilău mountains are in Figs 2 to 5.

Chemical compositions are well grouped in the gabbro-quartz diorite and tonalite (trondhjemite) fields (Fig. 2.a). Figs. 2.b and 2.c indicate a gap between acidic and mafic compositions typical for a bimodal magmatism. Figs. $3 \mathrm{a}$ and $3 \mathrm{c}$ indicate a predominantly sub-alkaline peraluminous character of the granitoids and an alkaline tendency of metaaluminous massive or sheared mafic rocks. In Fig. 4a, six out of 11 massive mafic rocks plot in the calc-alkaline field, one on the line and four in the tholeiitic fied. Trace element discrimination plots are shown in Figs. 4 b,c,d. Ti/Cr ratios for most mafic rocks of the Biharia assemblage correspond to the ocean floor basalts with the metamorphosed rocks towards low potassium tholeiites (Fig. 4.c). Seven of the Biharia mafic rocks show V/Ti ratios characteristic to a magmatic arc setting, three other only slightly higher values with only two samples showing OFB values (Fig. 4.b). $\mathrm{Zr}$ to $\mathrm{Y}$ ratios are closer to the Within Plate and Island Arc fields (Fig. 4.d). Ti/Zr ratio and the $\mathrm{Zr}$-Ti-Y ternary diagram show that most samples from the Biharia mafic rocks plot in the Calc-Alkaline Field with the rest either in the Low-K Tholeiite Field or outside the defined fields (Figs. 5.a and 5.b). 
IGNEOUS PROTOLITHS OF THE BIHARIA LITHOTECTONIC ASSEMBLAGE ...

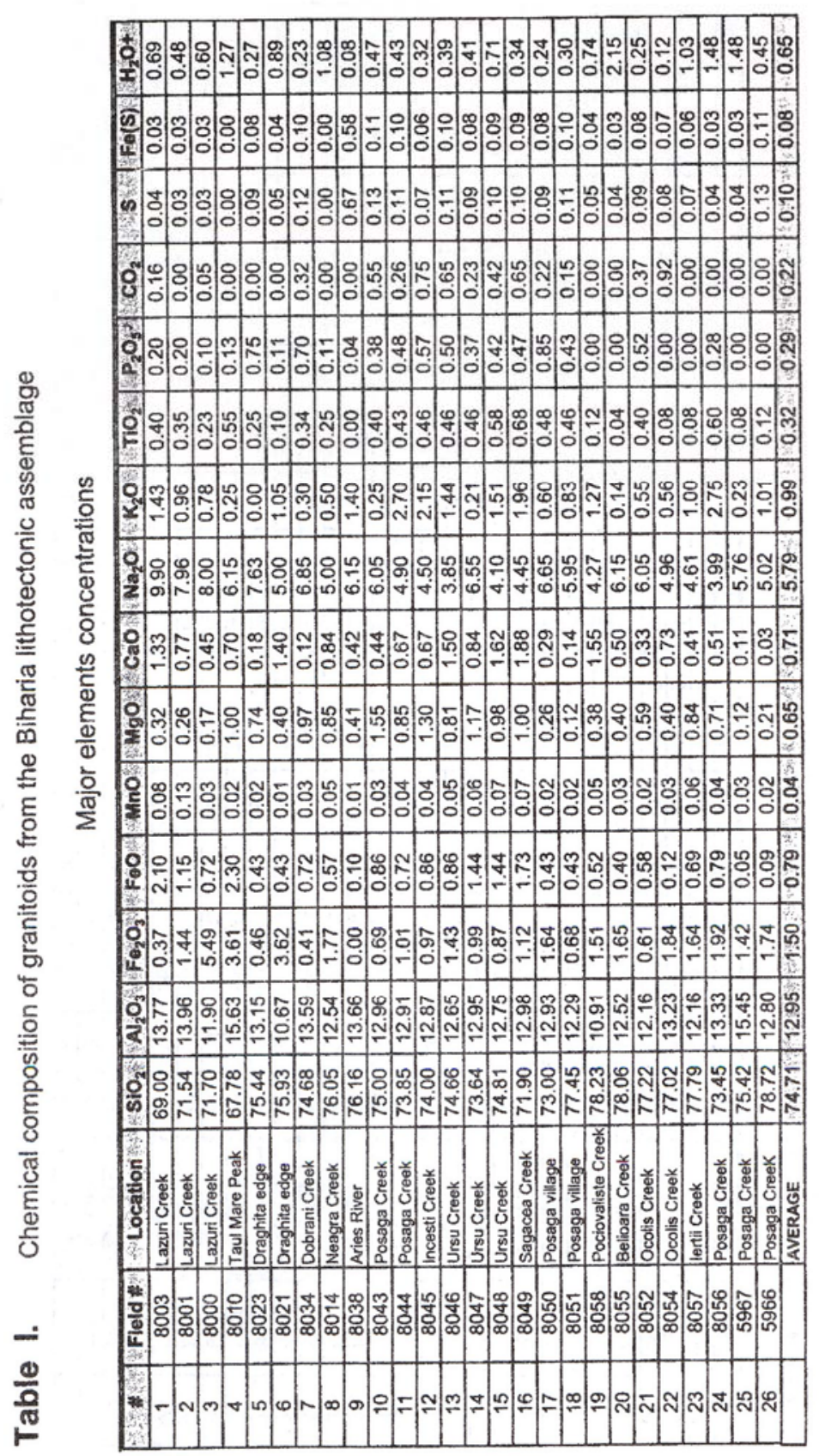




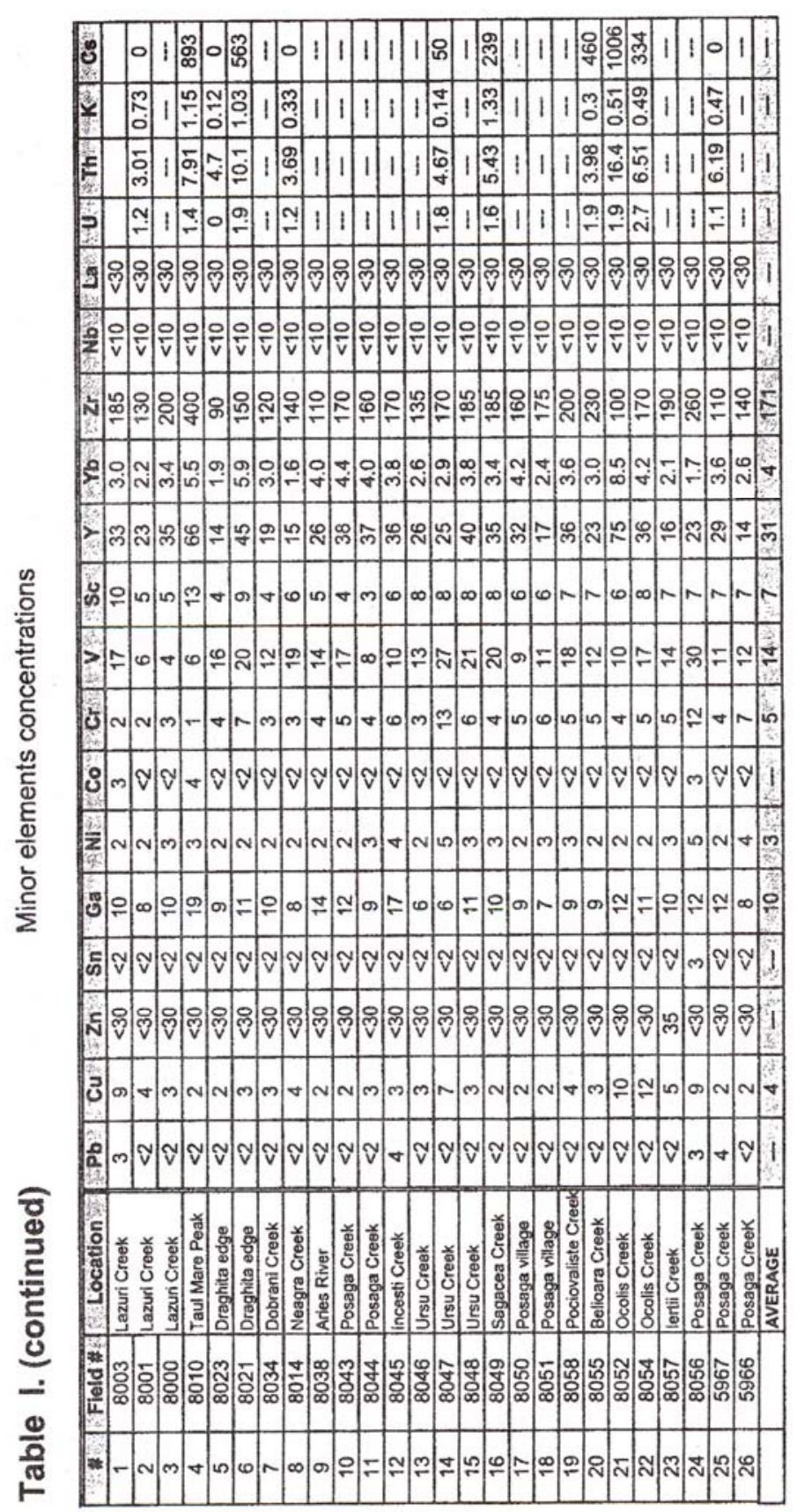


IGNEOUS PROTOLITHS OF THE BIHARIA LITHOTECTONIC ASSEMBLAGE ...

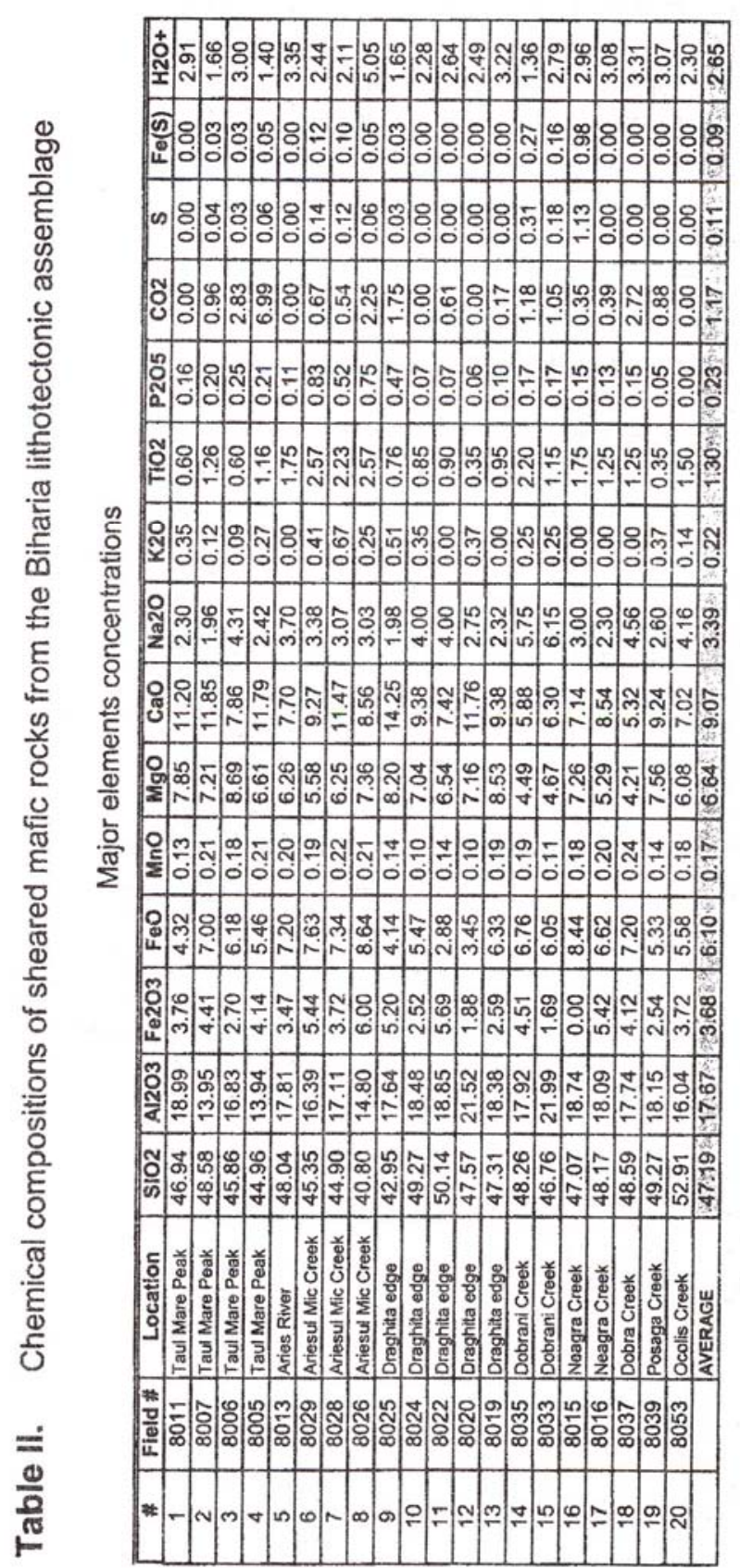




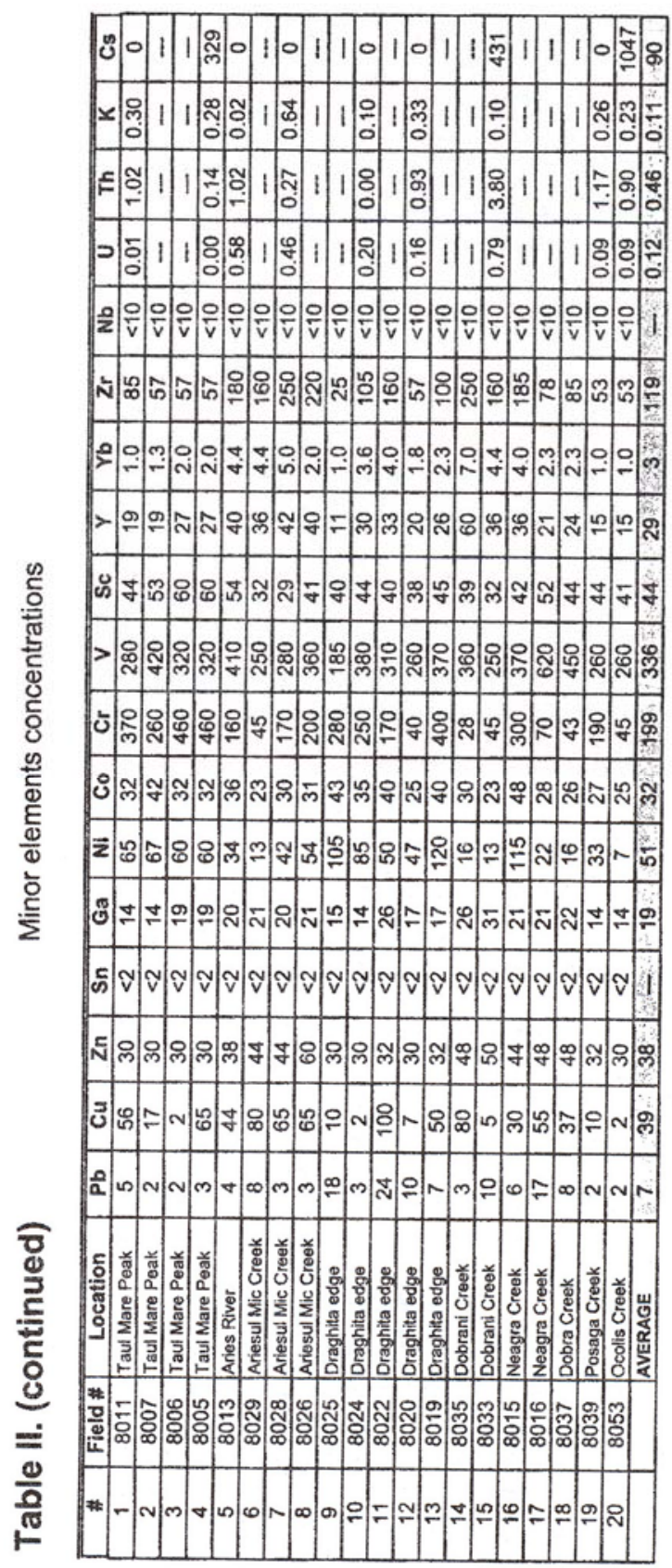


These data suggest that the meta-igneous rocks of the Biharia lithotectonic assemblage may have originated in a volcanic arc sequence. The large amount of granitoids that intrude the mafic rocks may represent a late re-melted arc material, when the arch thickened enough.
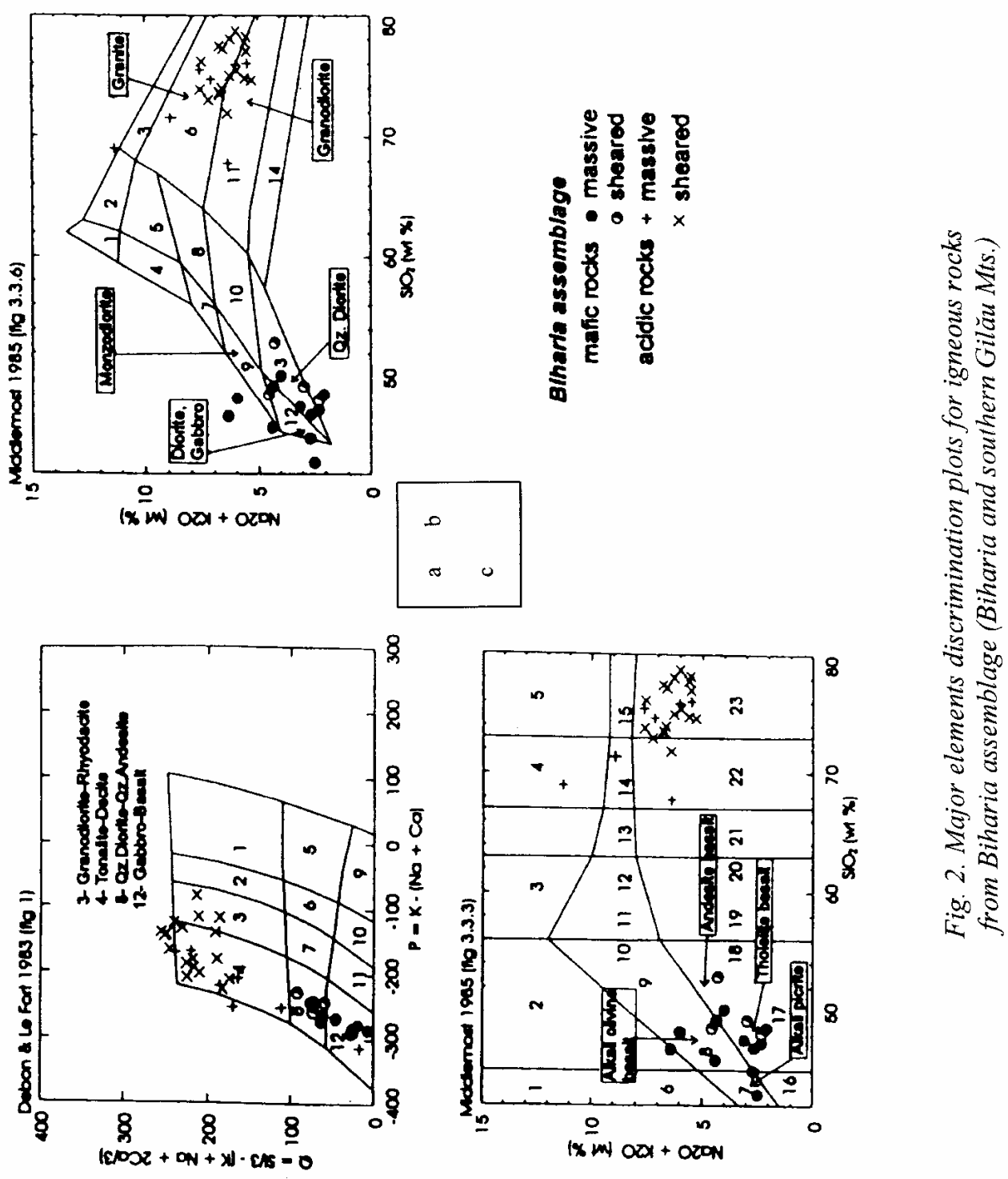

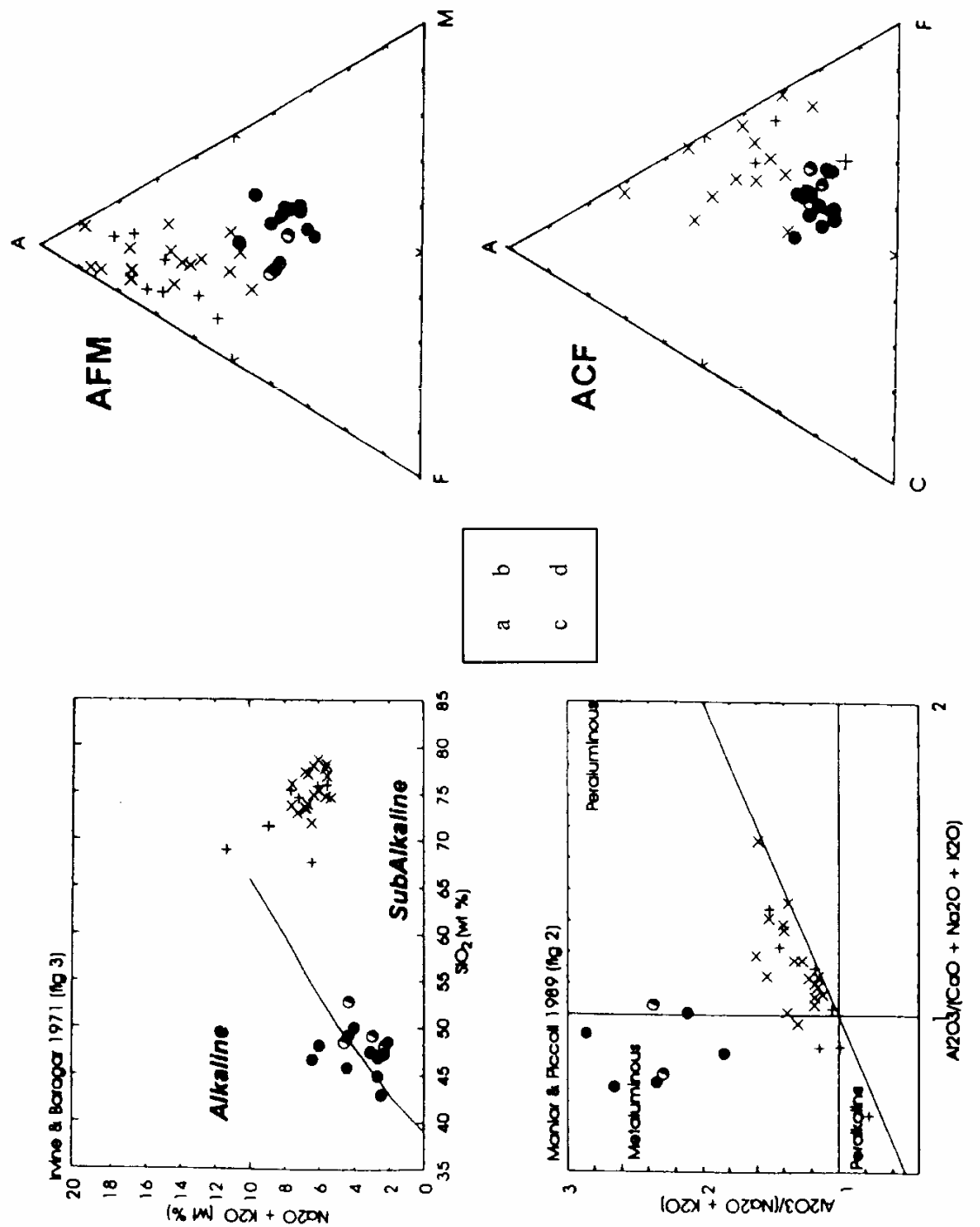

\section{U-Pb ZIRCON DATA}

\subsection{Analytical procedure}

In order to constrain the propose correlation of the Biharia and Highiş igneous complexes we collected one sample from the Ocolisel granite for $U$ $\mathrm{Pb}$ dating (Fig. 1). Three zircon fractions were analysed using the isotope dilution thermal ionization (TIMS) method at the University of Alberta. 


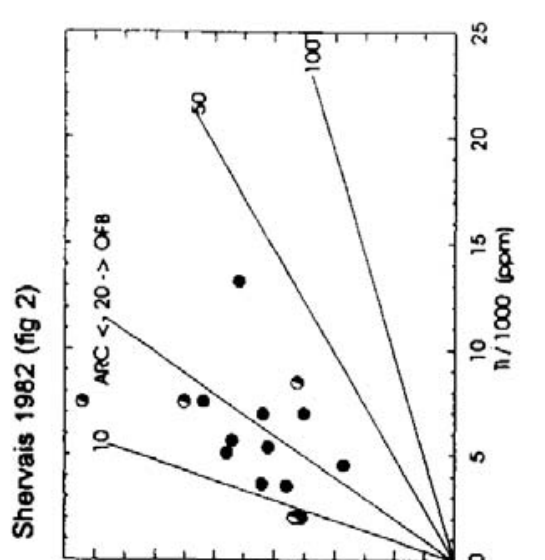

$88888888888889888^{\circ}$

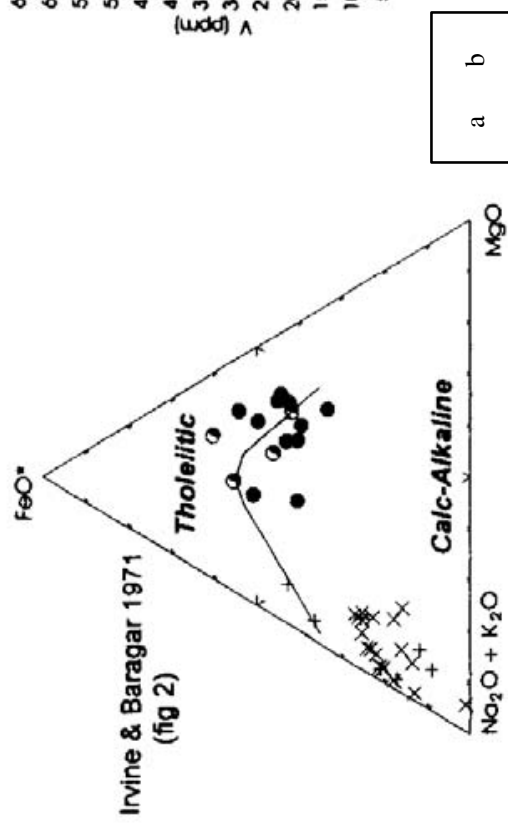

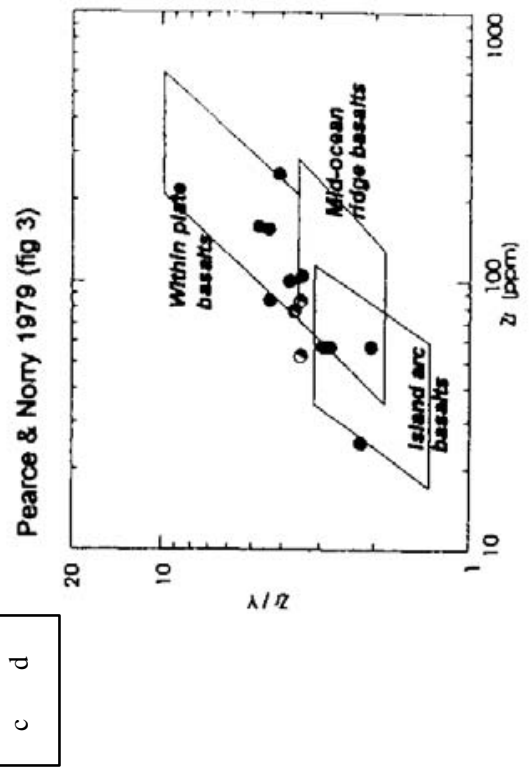

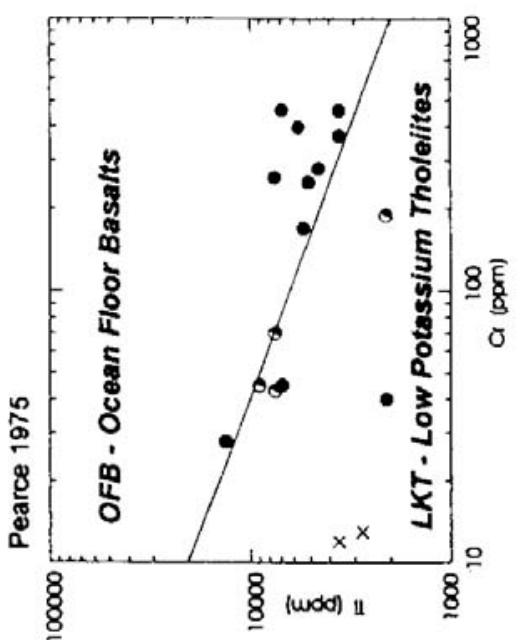

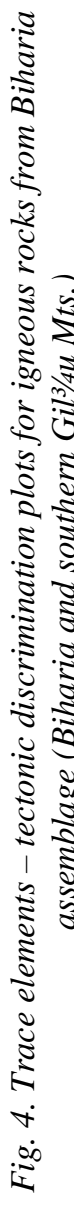

An approximately 14 kilogram-sample was pulverized to a fine powder with a jaw crusher and Bico disc mill and passed over a Wilfley table to concentrate heavy minerals. Zircon was separated using heavy liquid and magnetic mineral separation (see Heaman and Machado, 1992). 


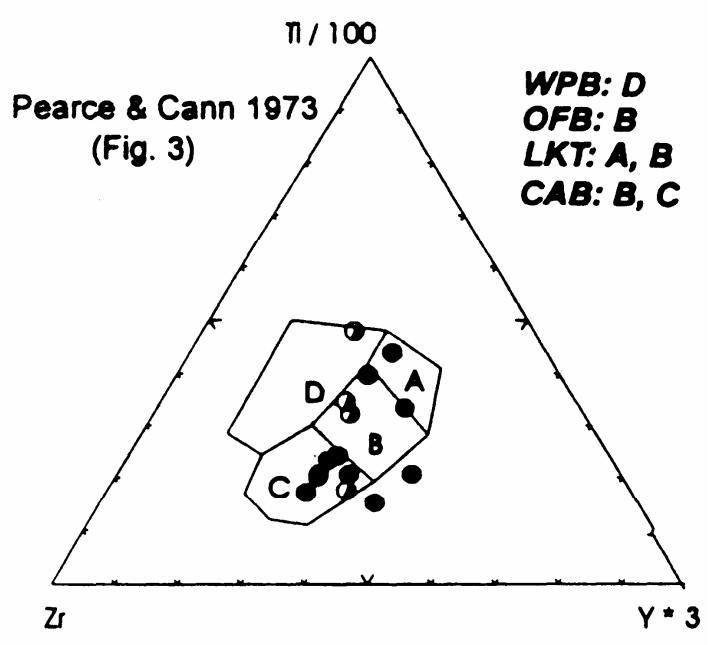

a

Pearce \& Cann 1973 (fig 2)

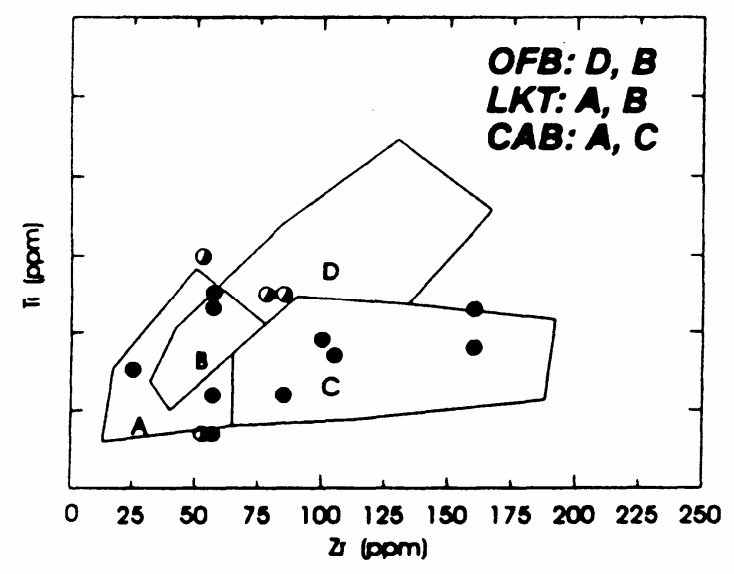

$b$
Within Plate Basalts (WPB)
Ocaan Floor Basalts (OFB)
Low Potassiun Thololtes (LKT)
Calc-Alkallne Basalts (CAB)

Fig. 5. Trace elements - tectonic discrimination plots for igneous rocks from Biharia assemblage (Biharia and southern Gilău Mts.) 
Individual zircon selection using a microscope was made to avoid grains with cracks, alteration, inclusions, or other imperfections, and multi-grain fractions were collected on the basis of distinct optical features and grain quality. All zircon fractions were washed prior to dissolution. Zircon fractions were spiked with a mixed ${ }^{205} \mathrm{~Pb}-{ }^{235} \mathrm{U}$ tracer solution (see Krogh and Davis, 1975). Sample dissolution and the extraction of $\mathrm{Pb}$ and $U$ followed closely the procedure of Krogh (1973). $\mathrm{Pb}$ and $U$ blanks were $3.5 \mathrm{pg}$ and $0.1 \mathrm{pg}$, respectively. $\mathrm{Pb}$ and $\mathrm{U}$ were loaded onto outgassed, single Re filaments in a silica gel-phosphoric acid mixture and analysed using a VG 354 mass spectrometer. $\mathrm{Pb}$ isotopic ratios were measured using a single Faraday cup collector. For a typical $\mathrm{Pb}$ load of $10 \mathrm{ng}$, the average beam intensity at mass 206 (at $1,450^{\circ} \mathrm{C}$ ) was $0.5 \times 10-11 \mathrm{~A}$ (1011 ohm resistor). All $\mathrm{Pb}$ and $\mathrm{U}$ isotopic data were corrected for mass fractionation using factors of $+0.088 \%$ lamu (atomic mass unit) for $\mathrm{Pb}$ and $+0.155 \%$ /amu for $\mathrm{U}$, from replicate analysis of the NBS-SRM 981 common Pb and NBS-SRM U 500 standards. For isotopic ratios measured with a Daly photomultiplier detector, a Daly-Faraday empirical conversion factor of $+0.13 \% / \mathrm{amu} \mathrm{Pb}$ and + 0.15/amu U was used.

Errors associated with $\mathrm{Pb} / \mathrm{U}$ and ${ }^{207} \mathrm{~Pb} /{ }^{206} \mathrm{~Pb}$ ratios were calculated with an in-house program that numerically propagates known sources of error. Initial common $\mathrm{Pb}$ isotopic composition was calculated using the model of Stacy and Kramers (1975). The regression line and error associated with age determination (quoted at the 95\% confidence level) were calculated using the ISOPLOT software (version 2.12, K. Ludwig, United States Geological Survey). Decay constants used for ${ }^{235} \mathrm{U}(9.8485 \mathrm{x}$ $10-10 \mathrm{yr}-1)$ and ${ }^{238} \mathrm{U}(1.55125 \times 10-10 \mathrm{yr}-1)$ and the isotopic composition of uranium (137.88) follow Jaffey et al. (1971) and the IUGS Subcommission on Geochronology (Steiger and Jäger, 1977).

\subsection{Results}

Three fraction of transparent, inclusion free zircon grains from the Ocolisel granite (sample 18) from southern Gilău Mountains yielded three near-concordant data points (Fig. 6 and Table III) indicating an emplacement age of $489.6 \pm 6.9 \mathrm{Ma}$.

This age confirms the Leucii Granite age, and suggests the accomplishment of the Biharia sequence igneous complex during latest Cambrian, earlyest Ordovician. The basic part of this complex which appears older than the granitic one was still not dated. 

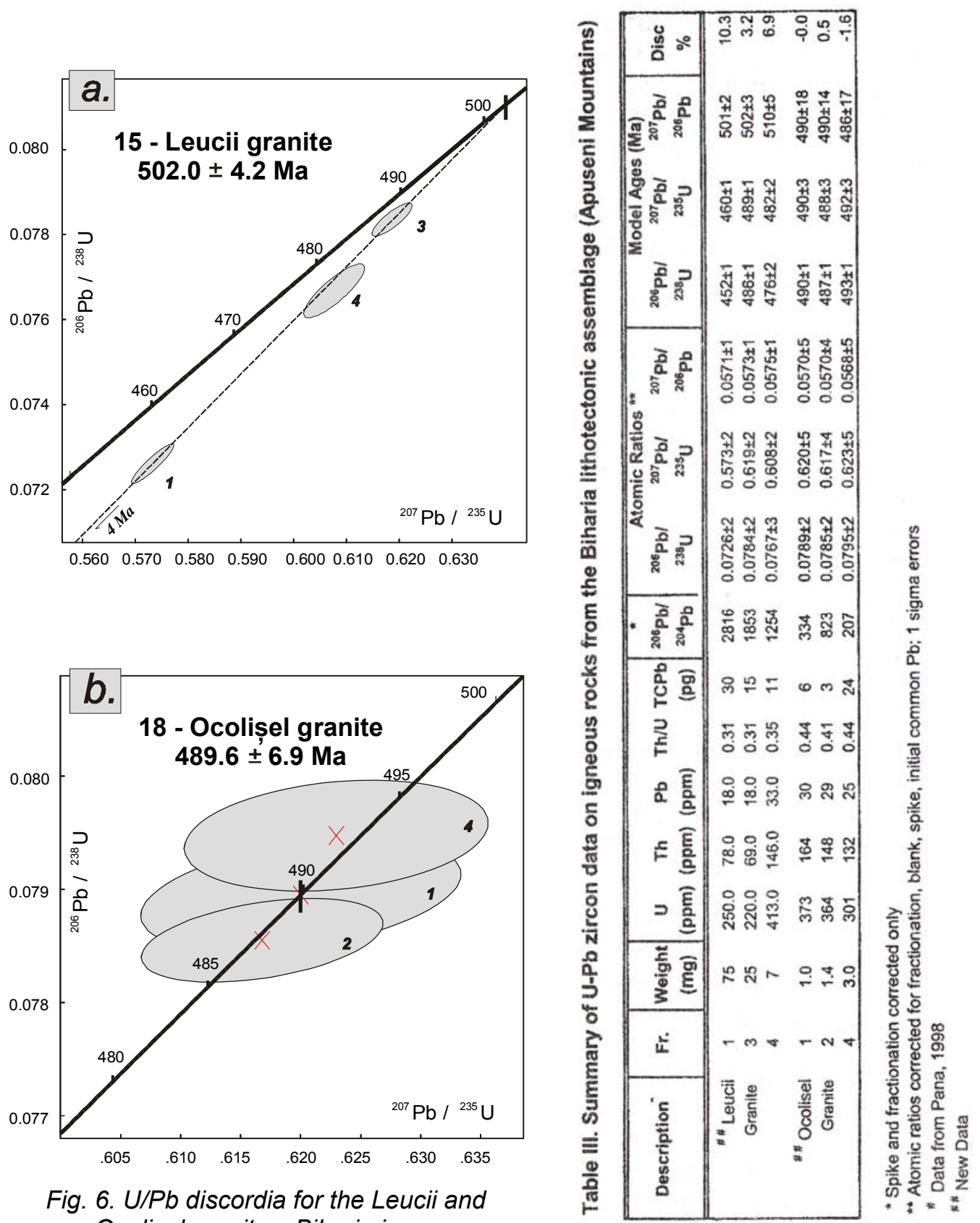

Fig. 6. U/Pb discordia for the Leucii and Ocolişel granites, Biharia igneous rock assemblage (Apuseni Mts.) 
IGNEOUS PROTOLITHS OF THE BIHARIA LITHOTECTONIC ASSEMBLAGE ...

\section{CONCLUSIONS}

Igneous pods within the Alpine HBSZ belong to two distinct magmatic events: in the eastern segment, the Biharia igneous complex emplaced in the latest Cambrian; in the western segment, the Highiş igneous complex emplaced in the late Early Permian. The age and general geochemical characteristics of the igneous pods within the Biharia lithotectonic assemblage place constraints on the pre-Alpine tectonic evolution of the crust exposed in the Apuseni Mountains. Interpretation of a Paleozoic plate configuration requires however, regional scale consideration and integration with the current Paleozoic plate-tectonic interpretation of the Alps and extra-Alpine Variscides (e.g., von Raumer and Neubauer, 1994; von Raumer, 1998). The Variscan evolution includes: a) Cambrian rifting; b) Ordovician initiation of convergence; c) Silurian drifting of peri-Gondwanian crustal fragments; d) Devonian - Early Carboniferous oblique collision, dominated by dextral transpression resulting in south-verging nappes; e) Late Carboniferous and Permian post-collisional evolution, dominated by transtension, development of sedimentary troughs, intrusion, extrusion of crustal and mantle-derived magmas, uplift, and erosion before the initiation of the Alpine cycle.

The c. 490 Ma Ocolisel granite and the c. 502 Ma Leucii plagiogranite, are the oldest dated intrusions in the Apuseni Mountains. They may record the latest Cambrian final stages of Pan-African crustal growth along the northern margin of Gondwana recognized in the Southern Alps and AustroAlpine region (see Pin, 1991, and Liégeois et al., 1995). The northern and southern gneiss terranes of the Apuseni Mountains are inferred to represent relics of two Precambrian crustal fragments in a complex Paleozoic interaction. The Late Cambrian-early Ordovician Biharia igneous belt is paralleled at the southern and eastern margin of the northern gneissic terrane by the amphibolite dominated Codru assemblage. ${ }^{40} \mathrm{Ar} /{ }^{39} \mathrm{Ar}$ plateau ages from hornblende in the Codru amphibolite range from c. 405 to c. $366 \mathrm{Ma}$ (Dallmeyer et al., 1999)

Two alternative tectonic models proposed herein require further detailed geochemical and isotopic testing.

1. The Codru amphibolitic assemblage and the Biharia igneous belt may represent a suture/magmatic arc pair between the northern gneissgranitic and the southern gneiss-carbonate terrane. Assuming that the only major rotation of the Apuseni - South-Pannonian block was the $\sim 100^{\circ}$ Tertiary rotation, the Biharia igneous belt may record the development of a Late Cambrian to Late Ordovician magmatic arc above a north-dipping subduction zone. Isotopic data from the Codru amphibolite may record the long-lasting tectonometamorphic evolution of a pre-Devonian ophiolitic relic. The strike-parallel stretching in the amphibolite, the lack of structural evidence for major thrusting and the absence of a contemporaneous spatially related magmatic arc suggest that the inferred Codru segment of the elusive Variscan suture formed by Devonian oblique collision between 
the Someş and the Baia de Arieş crustal fragments.

2. The Biharia igneous belt formed by Late Cambrian to Early Ordovician thinning, and underplating of continental crust with gabbrogranodiorite formed in a zone of maximum extension. During Devonian general oblique collision the rift-like setting became the locus of strain concentration and the Codru orthoamphibolite formed from most mafic rocks originally emplaced along the rift axis.

\section{ACKNOWLEDGEMENTS}

This paper was partially founded by the grant $46.174 / 1997$ theme 16, accorded by World Bank.

\section{REFERENCES}

1. Balintoni, I., (1985) - Corélation des unités lithostratigraphiques et tectoniques longeant le ruisseau d'Arieş entre la Vallée de lara et le Mont Găina (Monts Apuseni). D.S. Inst. Geol. Geofiz., LXIX/5, 5-15, Bucureşti.

2. Balintoni, I., (1986), Petrologic and Tectonic Features of the Highiş-Drocea Crystalline Massif, (Apuseni Mountains), D. S. Inst. Geol. Geofiz. 70-71/5 (1983;1984), 5 - 21, Bucureşti.

3. Balintoni, I., (1994), Structure of the Apuseni Mountains, in: Berza, T., (Ed.), "Geological evolution of the Alpine Carpathian-Pannonian system, ALCAPA II Conference, Field Guide-Book, Rom. Jour. Tect. Reg. Geol., 75. Suppl. 2, 51 58, IGR, Bucureşti.

4. Balla, Z., (1982), Development of the Pannonian Basin Basement through the Cretaceous-Cenozoic Collision: A New Synthesis, Tectonophysics, 88, 2, 61-102.

5. Csontos, L., Nagymarosy, A., Horváth, F., Kovác, M., (1992), Tertiary Evolution of the Intra-Carpathian Area: a Model, Tectonophysics, 208, 221-241.

6. Dallmeyer, R.D., Pana, D., Neubauer, F., and Erdmer, P., (1999), Tectonothermal evolution of the Apuseni Mountains, Romania: Resolution of Variscan vs. Alpine Events with 40Ar/39Ar ages, Journal of Geology, 107, 329-352.

7. Dimitrescu, R., (1985), Early Caledonian Event in the Pre-Alpine Metamorphic Sequences of the Romanian Carpathians, Acta Mineral. Petrogr., XXVII, 59-70.

8. Dimitrescu, R., (1988 ), Apuseni Mountains, in: Zoubek V., Cogné, J., Kozhoukharov, D., (Eds.): Precambrian In Younger Fold Belts., 665 - 674, John Wiley \& Sons, New York.

9. Giuşcă, D., (1979), Masivul cristalin al Highişului, St. Cerc. Geol. Geofiz. Geogr., (Geol.), 24, 15-43, Bucureşti.

10. Giuşcă, D., Savu, H., Borcoş, M., (1968), La stratigrafie des schistes cristallins des Monts Apuseni, Rev. Roum. Géol. Géophys. Gógr., Géol., 12, 2, 143-159.

11. Haas, J., Kovács, S., Krystyn, L., Lein, R., (1995), Significance of Late Permian - Triassic facies zones in terrane reconstructions in the Alpine North Pannonian domain, Tectonophysics, 242, 19-40. 
IGNEOUS PROTOLITHS OF THE BIHARIA LITHOTECTONIC ASSEMBLAGE ...

12. Hârtopanu, I., Hârtopanu, P., (1986), Intersecting isograds - a possible way to find out the polymetamorphism. An example: the Someş series, D.S. Inst. Geol. Geofiz., 70-71/1, 291-299.

13. Heaman, L.M., Machado, N., (1992), Timing and origin of mid-continent rift alkaine magmatism, North America: evidence from the Coldwell Complex, Contr. Miner. Petr., 110, 289-303.

14. Jaffey, A.H., Flynn, K.F., Glendenin, L.E., Bentley, W.C., Essling, A.M., (1971), Precison measurements of half-lives and specific activities of ${ }^{235} U{ }^{238} U$.Phys. Rev., C4, 1889-1906.

15. Kovács, S., Császár, G., Galácz, A., Haas, J., Nagy, E. and Vörös, A., (1989), The Tisza Superunit was originally part of the North Tethyan (European) margin. Mem. Soc. Geol. France, 154, (II), 81-100.

16. Kräutner, H.G., (1980), Lithostratigraphic Correlation of Precambrian in the Romanian Carpathians, An. Inst. Geol. Geofiz., LVII, 229-296.

17. Kräutner, H.G., (1988), Interregional correlations, in Zoubek V., Cogné, J., Kozhoukharov, D., (Eds.): Precambrian in Younger Fold Belts, 853-862, John Wiley \& Sons, New York.

18. Krogh, T.E., (1973), A low-contamination method for hydrothermal decomposition of zircon and extraction of $U$ and $P b$ for isotopic age determinations. Geochim. Cosmochim. Acta, 37, 485-449.

19. Krogh, T.E., Davis, G. L., (1975), The production an preparation of ${ }^{205} \mathrm{~Pb}$ for use as a tracer for isotope dilution analyses. Carnegie Inst. Washington Yearb., 74, 416-417.

20. Liégeois, J.P., Berza, T., Tatu, M., and Duchesne, J.C., (1996), The Neoproterozoic Pan-African basement from the Alpine lower Danubian nappe system (South Carpathians, Romania). Precambrian Research, 80, 3-4, 281-301.

21. Márton, E., Mauritsch, H.J., (1990), Structural application and discussion of a paleomagnetic post-Paleozoic data base for the Central Mediterranean, Physics of the Earth and Planetary Interiors, 62, 46-59.

22. Pană, D., (1998), Petrogenesis and Tectonics of the Basement Rocks of the Apuseni Mountains: Significance for the Alpine Tectonics of the CarpatianPannonian Region. Ph.D. Thesis, Univ of Alberta, Canada.

23. Pană, D., Erdmer, P., (1994), Alpine crustal shear zones and pre-Apline basement terranes in the Romanian Carpathians and Apuseni Mountains. Geology, 22, 807-810.

24. Pană, D., Ricman, C., (1988), The lower complex of the Păiuşeni series - a blastomylonitic shear belt. Rev.Roum. Géol. Géophys. Géogr., Géologie, 32, 21-35.

25. Pană, D.; Erdmer, P., Dallmeyer, R. D., (1996). Litho-tectonic assemblages of the Apuseni Mountains: strain partitioning and timing of tectonism. Rom. J. Tec. Reg. Geol. 76:168-172.

26. Pavelescu, L., Pop, G., Ailenei, G., Soroiu, M., Popescu, G., (1975), $\mathrm{K}-$ Ar age determinations from the Apuseni and Banat Mountains. Rev. Roum., Géophys., 19, 67-69.

27. Pin, C., (1991), Central-Western Europe: Major Stages of Development During Precambrian and Paleozoic Times, in: Dallmeyer, R. D. Lecorche, J. P. (Eds.), Tectonothermal evolution of the West African orogens and circum Atlantic terrane linkages, Berlin 295 - 306, Springer-Verlag. 
28. Raumer, J. F., von, (1998), The Paleozoic evolution in the Alps: from Gondwana to Pangea, Geol. Rundsch., 87, 407-435.

29. Raumer, J. F., von, and Neubauer, F. (1993). Late Precambrian and Paleozoic Evolution of the Alpine Basement: an overview. In: Raumer, J. von, and Neubauer, F., (Eds.), Pre-Mesozoic geology in the Alps., 625-639, Springer, Berlin.

30. Raumer, J. F., von, Neubauer, F., (1994), The Paleozoic Evolution of the Alps, Schweiz. Mineral., Petrogr. Mitt., 74, 459-467.

31. Săndulescu, M., (1988), Cenozoic Tectonic History of the Carpathians, in: Royden, L., Horváth, F., (Eds.), The Pannonian Basin - A Study in Basin Evolution, AAPG Memoir, 45, 17-25.

32. Savu, H., (1965), Masivul eruptiv de la Bârzava (Munții Drocea), Mem., Com. Geol., VIII, 148p., Bucureşti.

33. Soroiu, M., Popescu, G., Kasper, U., Dimitrescu, R., (1969), Contributions préliminaires à la géochronologie des massifs cristallins des Monts Apuseni. An. t. Univ. "Al. I. Cuza", Secț. II, b, (Geologie), XV, 25-33, Iaşi.

34. Stacey, J.S., Kramers, J.D., (1975), Approximation of Terrestrial Lead Isotope Evolution by a Two Stages Model. Earth. Plan. Sci. Lett., 26, 207-221.

35. Steiger, R.H., Jäger, E., (1977), Subcomission on constants in Geo- and Cosmochronology. Earth. Planet. Sci. Lett., 36, 359-362.

36. Tatu, M., (1998), Le Massif Highiş (Roumanie) un exemple de l'evolution du magmatisme alcalin anorogenique. Thèse, Université de Paris-Sud, centre d'Orsay. 